\title{
Assessing Climate Change Impact on Future Reference Evapotranspiration Pattern of West Bengal, India
}

\author{
Saon Banerjee", Benukar Biswas ${ }^{2 *}$ \\ ${ }^{1}$ Department of Agricultural Meteorology and Physics, Bidhan Chandra Krishi Viswavidyalaya, Mohanpur, India \\ ${ }^{2}$ All India Coordinated Research Project on Agroforestry, Department of Agronomy, Bidhan Chandra Krishi Viswavidyalaya, \\ Mohanpur, India \\ Email: ^kripahi@yahoo.com
}

How to cite this paper: Banerjee, S. and Biswas, B. (2020) Assessing Climate Change Impact on Future Reference Evapotranspiration Pattern of West Bengal, India. Agricultural Sciences, 11, 793-802. https://doi.org/10.4236/as.2020.119051

Received: August 23, 2020

Accepted: September 22, 2020

Published: September 25, 2020

Copyright ( 2020 by author(s) and Scientific Research Publishing Inc. This work is licensed under the Creative Commons Attribution International License (CC BY 4.0).

http://creativecommons.org/licenses/by/4.0/

(c) (i) Open Access

\begin{abstract}
Considering the importance of reference evapotranspiration (RET) in agriculture, hydrology and meteorology, the research problem was taken to assess the RET during winter season under projected climatic situation of West Bengal, India. The Penman-Monteith method was used in the study as it is the most accurate method of estimating RET. However, validation of the output of the equation was done with the help of observed data set. The data analysis was carried out using NCAR Command Language (NCL). The result clearly shows that the reference ET of the study area will be increased in the tune of $13 \%$ to $32 \%$ in the year 2050 compared to present RET level. Analysis of actual rainfall data shows a decreasing trend of winter rainfall in the study region. The projected rainfall data also follows the same pattern. Thus, the combination of low rainfall and higher ET value will demand more irrigation requirement for winter crops in West Bengal. The temporal changes of RET on decadal basis and spatial variation of RET for each decade have been observed and discussed in the paper.
\end{abstract}

\section{Keywords}

Climate Change, Reference Evapotranspiration, Penman-Monteith Method, NCAR Command Languages, West Bengal

\section{Introduction}

The most precious input for agricultural operations is water and scarcity of freshwater poses a threat to agriculture. The ever-increasing population is the main cause of decreasing fresh water availability per capita. The combination of 
climate change and scarcity in water availability will be the main challenges in front of agricultural scientists and stakeholders. A research study shows Mediterranean regions may experience $2 \%$ - 15\% decrease of freshwater resources for $2^{\circ} \mathrm{C}$ of warming [1]. Similarly, $2^{\circ} \mathrm{C}$ rise in global temperature will affect one-fifth of the world population on severe water shortages issues [2]. Farmers of Asian countries generally use $80 \%-90 \%$ of their fresh water resources for agricultural operations. Assessment of water availability is the main pre-requisite for proper management of water for crop production and in this regard, the assessment of future evapotranspiration pattern is a prime challenge [3] [4] [5].

The regional change in evapotranspiration (ET) pattern has been increased manifold during past few decades [6] [7]. The close relationship between climatic elements and ET governs the temporal trend and variation of ET [8] [9]. The agricultural hydro-meteorologists give due importance on vegetation properties in estimating the ET. Potential evapotranspiration (PET) is one of the most important components of the hydrological cycle [10] and it measures the potentiality of the atmosphere to remove water from the surface through ET with an assumption that there is no dearth of water supply [11]. Thus, PET indicates the maximum water that can be lost from a vegetated surface with the exception that unlimited amount of water is available. Over land surfaces, the estimate of reference evapotranspiration (RET) is preferred [12] and the Penman-Monteith method has proved to be the most accurate method of estimating RET [13]. RET is the rate at which readily available soil water is vaporized from specified vegetated surfaces [14]. Then, reference evapotranspiration is defined as the ET rate from a uniform surface of dense, actively growing vegetation having specified height and surface resistance, not short of soil water, and representing an expanse of at least $100 \mathrm{~m}$ of the same or similar vegetations [15]. The concept of the RET was introduced to study the evaporative demand of the atmosphere independent of crop type, crop development, and management practices.

In India, West Bengal (WB) is such a state where the major agro-climatic regions exist, ranging from Hill Zone to Coastal Zone, along with alluvial and lateritic zone [16]. In this State, monsoon season crops are totally dependent on rainfall and rice is mainly grown in this season. On the other hand, pre-monsoon and winter season crops are mainly dependent on irrigation. The irrigation water requirement in winter season of Indian subcontinent including West Bengal is largely dependent up on ET variation. Due to climatic projections, the temperature enhancement for the tropical countries like India is inevitable and the temperature enhancement will affect the evapotranspiration pattern significantly. Considering the background, present research work aims to assess the RET during winter season under projected climatic situation of West Bengal, India.

\section{Materials and Methods}

\subsection{Study Area}

The study was done in West Bengal state (Lat. $21^{\circ} 25^{\prime}-27^{\circ} 13^{\prime} \mathrm{N}$ and Long. $85^{\circ} 50^{\prime}$ 
$\left.-89^{\circ} 50^{\prime} \mathrm{E}\right)$ situated in the eastern region of India along the Bay of Bengal considering the weather data from 1981 to 2019. It is the fourth-most populous state of India with over 91 million inhabitants. The Himalayan hill region in the northern extreme of the state is a part of the eastern Himalayas mountain range. The narrow Terai region separates the hills from the North Bengal plains, which in turn transitions into the Ganges delta towards the south. The red and lateritic zone intervenes between the Ganges delta in the east and the western plateau and high lands. A small coastal region is in the extreme south, where world heritage site Sunderban is situated. The main river in West Bengal is the Ganges, which flows through West Bengal as the Bhagirathi River and Hooghly River. Main rivers in Northern Bengla are Teesta, Torsa, Jaldhaka and Mahananda rivers are in the northern hilly region. The Ganges delta and the Sundarbans area have numerous rivers and creeks. West Bengal's climate varies from tropical savanna in the southern portions to humid subtropical in the north. The main seasons are summer, the rainy season, a short autumn and winter. While the summer in the delta region is noted for excessive humidity, the western highlands experience a dry summer like northern India. The highest daytime temperatures range from $38^{\circ} \mathrm{C}$ to $45^{\circ} \mathrm{C}$. Winter is mild over the plains with average minimum temperatures of $15^{\circ} \mathrm{C} .70 \%$ to $75 \%$ rainfall is received through South-West Monsoon rain. The location of the study area is shown in Figure 1.

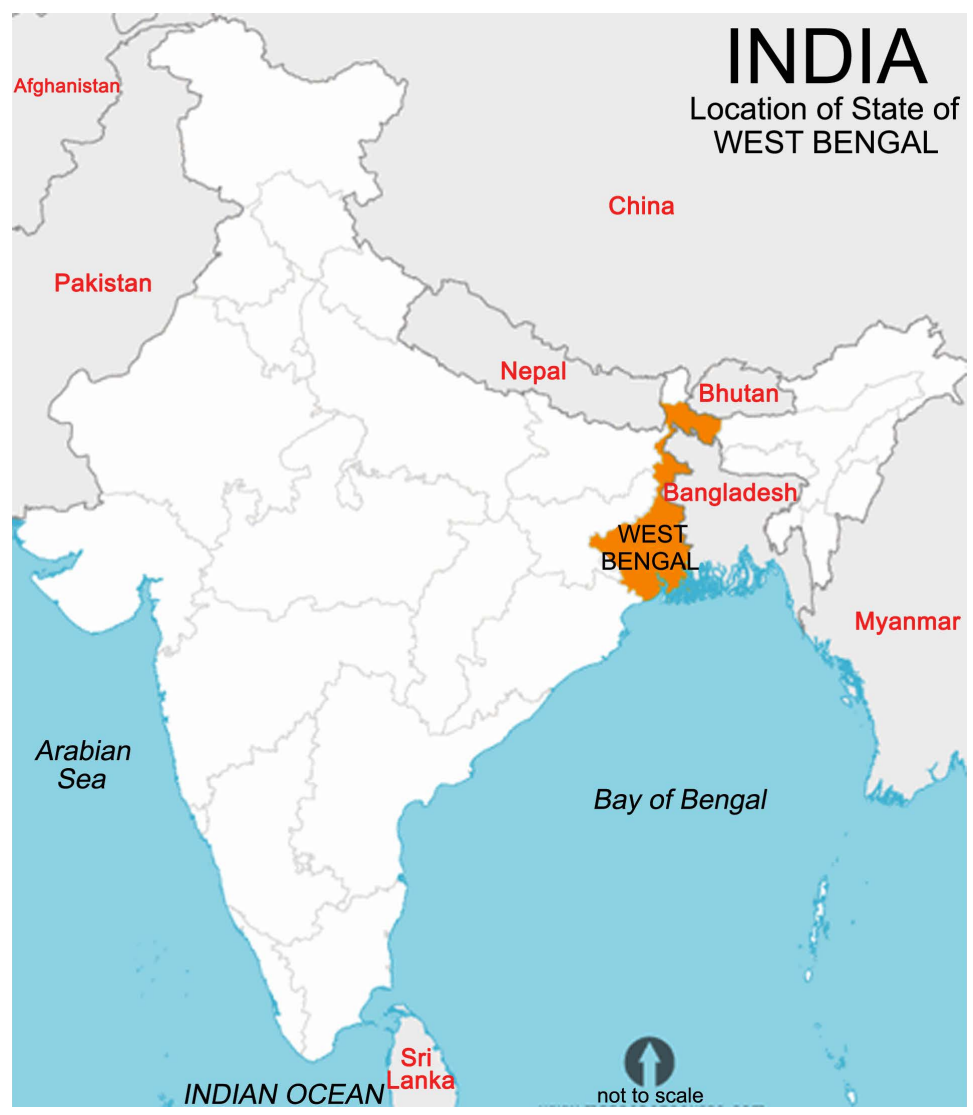

Figure 1. The location of the study area, West Bengal State. 


\subsection{Projection of Future Climatic Scenario}

To observe the impact of the projected climatic scenario, the weather prediction outputs of the regional climate model PRECIS (Providing Regional Climates for Impact Studies) were used. As the study area is under Eastern India, the A2 scenario was taken into account [17]. The future climatic scenario for next four decades (up to 2060) was generated from HadCM3Q through downscaling with $25 \mathrm{~km}$ spatial resolution. The PRECIS output on temperature, solar radiation and wind speed are used to assess the future RET.

\subsection{Calculation of Reference Evapotranspiration}

The Penman-Monteith method was used for calculation of reference evapotranspiration as follows [18]:

$$
\mathrm{RET}=\frac{0.408 \Delta\left(R_{a}-G\right)+\gamma \frac{900}{T+273} u_{2}\left(e_{s}-e_{a}\right)}{\Delta+\gamma\left(1+0.34 u_{2}\right)}
$$

where,

$$
\begin{aligned}
& \text { RET = Reference evapotranspiration }(\mathrm{mm} \text { per day }) \\
& R_{a}=\text { Net radiation at the crop surface }\left(\mathrm{MJ} / \mathrm{m}^{2} \text { per day }\right) \\
& G=\text { Soil heat flux density }\left(\mathrm{MJ} / \mathrm{m}^{2} \text { per day }\right) \\
& T=\text { Mean daily air temperature at } 2 \text { m height }\left({ }^{\circ} \mathrm{C}\right) \\
& u_{2}=\text { Wind speed at } 2 \mathrm{~m} \text { height }(\mathrm{m} / \mathrm{s}) \\
& e_{s}=\text { Saturation vapour pressure }(\mathrm{kPa}) \\
& e_{a}=\text { Actual vapour pressure }(\mathrm{kPa}) \\
& e_{s}-e_{a}=\text { Saturation vapour pressure deficit }(\mathrm{kPa}) \\
& \Delta=\text { Slope of vapour pressure curve }\left(\mathrm{kPa} \text { per }{ }^{\circ} \mathrm{C}\right) \\
& \gamma=\text { Psychometric constant }\left(\mathrm{kPa} \text { per }{ }^{\circ} \mathrm{C}\right)
\end{aligned}
$$

As already stated, the climatic outputs of the PRECIS RCM (temperature, solar radiation and wind speed) for whole State of West Bengal are used as input parameters of RET calculation. However, several parameters, like atmospheric pressure, latent heat of vaporization, psychrometric constant, etc., were derived from other known parameters as recommended in http://edis.ifas.ufl.edu/ website. The Net radiation was calculated by the process adopted from Riahi et al., 2003 [19]. In the calculation process, the effect of soil heat flux (G) is ignored for daily calculations as the magnitude of the flux in this case is relatively small.

\subsection{Analysis of Data}

Analysis of data was done by the NCAR Command Language (NCL). NCL is an interpreted programming language, specifically designed for the access, analysis, and visualization of data. NCL has many features common to modern programming languages, including types, variables, operators, expressions, conditional statements, loops, and functions and procedures. Binaries are free in this program and are available for most common Linux/Unix, MacOSX and Cygwin (Windows). 


\section{Results and Discussion}

\subsection{Variation of Past Rainfall Pattern and Future Climatic Trends}

The weekly-basis rainfall data, for the period of 1980 to 2019, are analysed to observe the past rainfall trend of West Bengal. The observed data of eight different stations collected from different agro-climatic zones are averaged and the decadal changes are shown in Figure 2. This figure shows the variation of weekly rainfall of winter season (SMW-1 to SMW-8). It is clear from the figure that average value of weekly rainfall is less in recent decade (2011-2019) compared to previous ones. During 1991-2000, the mean total rainfall of week number-1 to week number- 8 was $40.55 \mathrm{~mm}$.

For future climatic data of Gangetic West Bengal, CMIP5 (Climate Model Inter-comparison Projects) projections were considered. The average climatic trend of different decades for RCP 8.5 scenario is shown in Table 1. The time-series data of rainfall was plotted and from the linear equation of time versus rainfall data provided the trend. Similarly temperature trend was also calculated. Both the maximum and minimum temperatures follow an increasing trend for all future decades under study. The rainfall shows a decreasing trend for major part of the study period. The downscaled PRECIS model also indicated the similar trend. For spatial downscaling the most popular Delta method is used for the study. Array of equations are used for the whole process, among which the most common one is as follows:

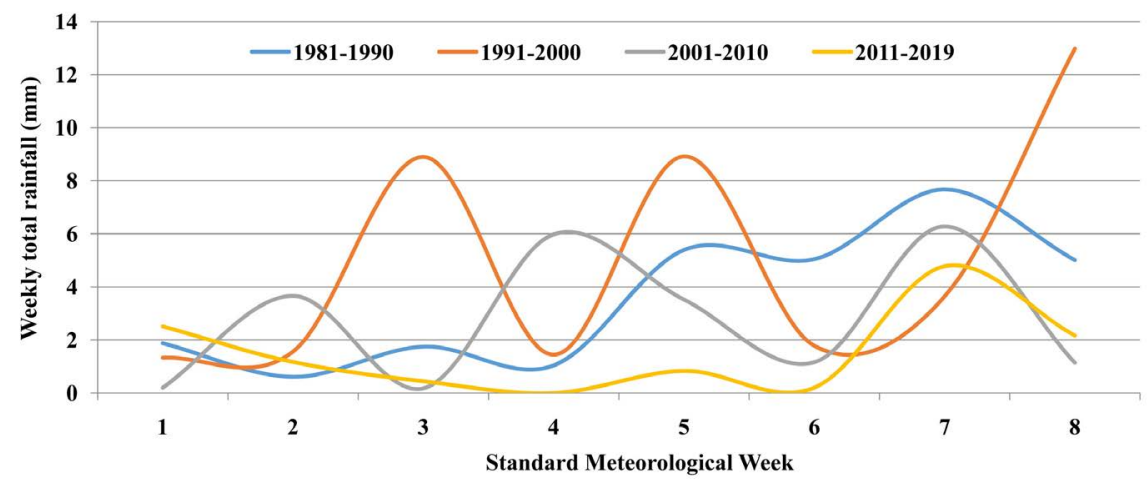

Figure 2. Variation of weekly total rainfall of West Bengal.

Table 1. The trend of future temperature and rainfall over Gangetic Plains of West Bengal.

\begin{tabular}{cccc}
\hline Year & $\begin{array}{c}\text { Maximum temperature trend } \\
\left({ }^{\circ} \mathrm{C} \text { per year }\right)\end{array}$ & $\begin{array}{c}\text { Minimum temperature trend } \\
\left({ }^{\circ} \mathrm{C} \text { per year }\right)\end{array}$ & $\begin{array}{c}\text { Rainfall trend } \\
(\mathrm{mm} \text { per year })\end{array}$ \\
\hline 2030 & 0.014 & 0.017 & -5.51 \\
2040 & 0.004 & 0.019 & 18.64 \\
2050 & 0.024 & 0.037 & -9.47 \\
2060 & 0.031 & 0.057 & -17.35 \\
\hline
\end{tabular}




$$
X_{F . i}=X_{C . i}+\Delta X_{I . i}
$$

where,

$X_{F, i}$ is the future value of the pixel for the variable $X$ (i.e. precipitation, temperature), in the month $\mathrm{i}$,

$X_{C, i}$ is the current value (i.e. from WorldClim) of the pixel for the variable $X$, in the month $i$,

$\Delta X_{I . i}$ is the interpolated value of the delta or anomaly corresponding to the pixel, for the variable $X$, in the month $i$.

Hence downscaled HadCM3Q (which is available at finer resolution) is used for the study.

\subsection{Validation of Penman-Monteith (PM) Method}

Before projection of the reference ET, the validation of PM method was done with actual RET data collected from India Weather Portal accessed through https://www.indiawaterportal.org/met_data. The generated RET values (termed as RET_PM) of winter season (January and February for the years 1998 to 2002) for three different agro-climatic zone was plotted against the RET value obtained from the said portal (termed as RET_IP). Through scattered diagram, it is observed that the data set are very well matched and they are along with 1:1 line (Figure 3). The average winter season RET was also very close to the data generated by Verma et al., 2008 [20]. Once the calculation process was well established, the projection of future RET had been done.

\subsection{Assessment of Future RET Pattern}

The winter season RET (for January and February months) for whole WB state was worked out for 2030, 2040, 2050 and 2060. To obtain the more-reliable result and smoothen the effect of climatic extremes, the average of five years RET was considered for a particular decade. For example, the map of 2030 shows the mean RETs of 2028 to 2032. The RET pattern for 2030 shows that in very small portion of Western and Northern WB, the seasonal RET will be highest, varying from 360 to $380 \mathrm{~mm}$ per season (Figure 4 (a)). In the southern or coastal zone,

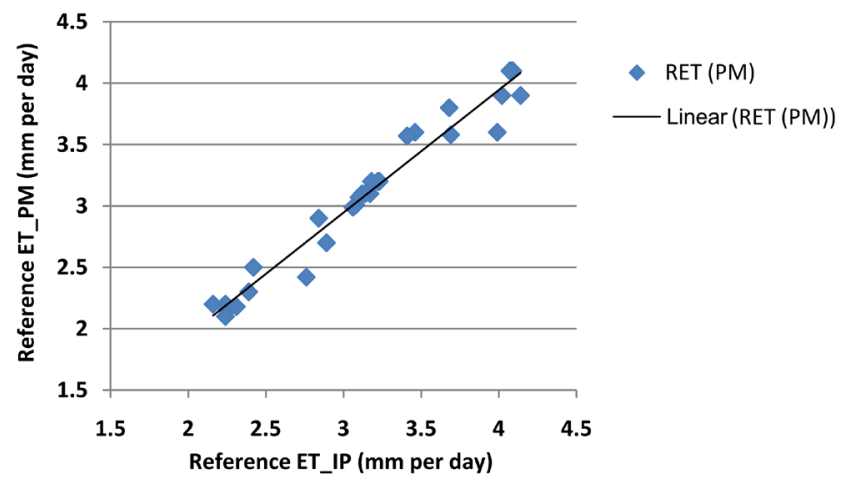

Figure 3. Variation RET calculated by Penman-Monteith method (RET_PM) and RET obtained from India weather portal $\left[y=0.998 x-0.050 ; R^{2}=0.961\right]$. 


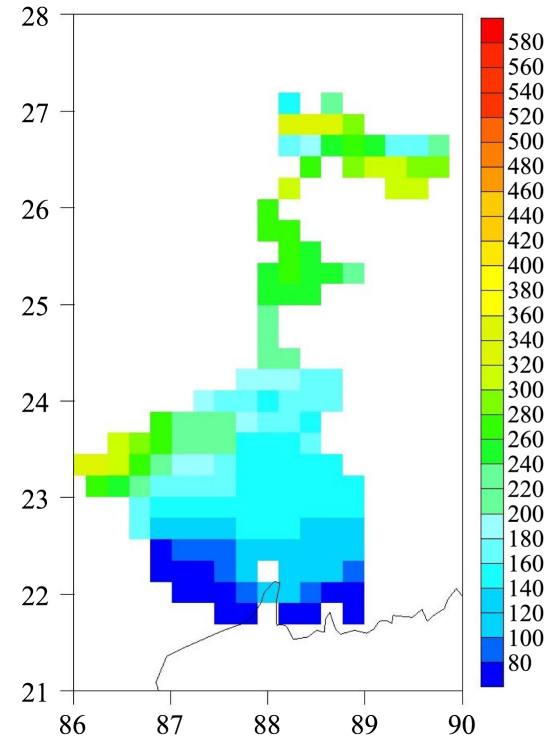

(a)

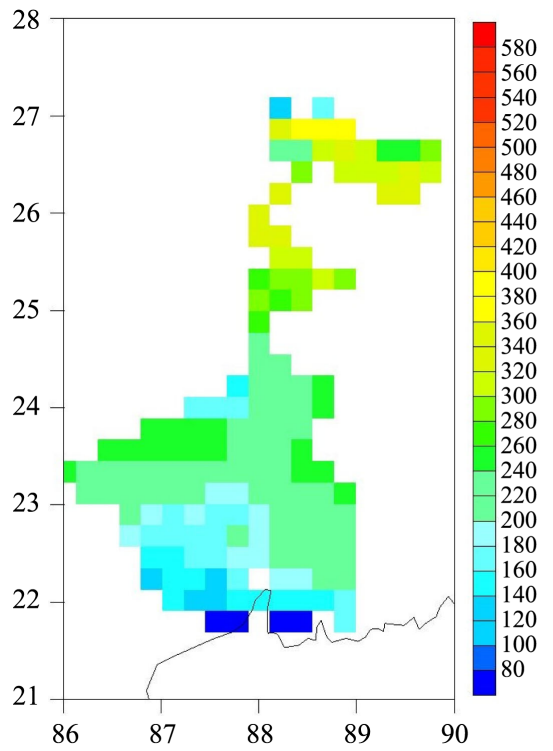

(c)

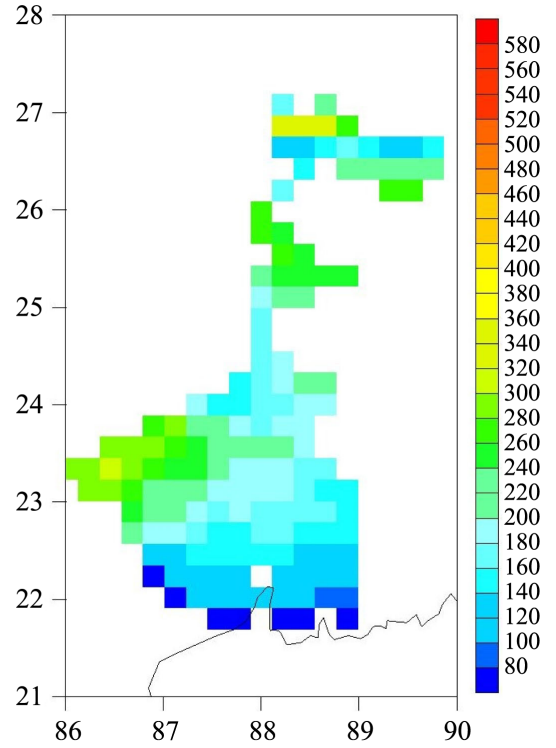

(b)

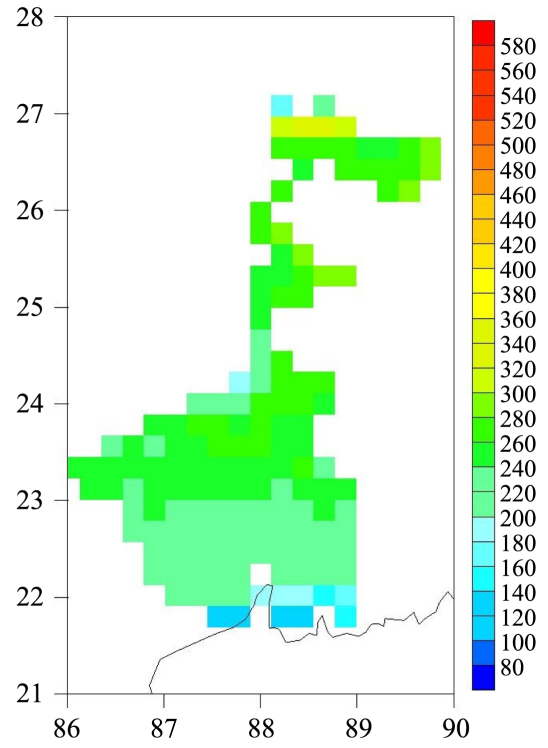

(d)

Figure 4. Climate change impact on future reference ET pattern of west Bengal, India during. (a) 2030; (b) 2040; (c) 2050; (d) 2060.

the RET will be very low, only up to $100 \mathrm{~mm}$ per season which is almost similar to the present level value. In the major parts of Gangetic WB (22030'N to $240 \mathrm{~N}$ and $870 \mathrm{E}$ to $890 \mathrm{E}$ ), the mean RET is $180 \mathrm{~mm}$ per season. Hence three distinct category of RET can be observed in the study area as follows:

Category I: Below $100 \mathrm{~mm}$ per season observed in the coastal area (Southern most part of WB)

Category II: 100 to $350 \mathrm{~mm}$ per season covering major areas in WB

Category III: Above $350 \mathrm{~mm}$ per season, observed in the Western WB and at higher latitudes 
In 2040, the area under "Category I" will be reduced indicating increased RET pattern in the coastal zone (Figure 4(b)). The RET values will also be increased in the western part of the state. In 2050, the Northern WB may observe higher amount of RET (Figure 4(c)). This will demand more irrigation water requirement in the zone. The RET values of some parts of Northern WB is $400 \mathrm{~mm}$ per season (i.e. $6.6 \mathrm{~mm}$ per day), which is as high as $31.8 \%$ more than the present level. However in the major portion of Southern WB, the RET enhancement will be around $13.0 \%$ compared to present level. Tao et al. (2015) [21] observed the ET increases by $10.2 \%, 19.1 \%$, and $27.3 \%$ under the RCP 85 scenario during the periods from 2011 to 2040, from 2041 to 2070, and from 2071 to 2100, respectively in Xiangjiang River Basin, China. In 2060, the RET of Northern WB will be reduced (Figure 4(d)), which is due to the lower magnitude of projected solar radiation data. In 2060, the southern part of WB will experience more RET and the state-level spatial variation of RET will be reduced.

\section{Conclusion}

The present research work clearly shows the reference ET of the study area will be increased in the tune of $13 \%$ to $32 \%$ in the year 2050 compared to present RET level. It is also very much clear from actual data set and from generated data that the amount of rainfall will decrease in the study area for winter season. Thus, the combination of low rainfall and higher ET value demands more irrigation requirement for proper crop growth in the study region. The irrigation water requirement for growing winter season crops will be higher in the northern part of WB than the southern part in future. The temporal changes of RET over decades will be less in Gangetic WB up to 2050 and the spatial variation of RET in the state will be reduced in 2060 . The present research work will help the hydrologists, meteorologists and planners to develop water management options under climate change scenario.

\section{Acknowledgements}

Authors acknowledge the help of Prof. Simon Tett of Edinburgh University for his guidance and encouragement. Both the authors acknowledge the help of Director of Research and Dean, Faculty of Agriculture, BCKV.

\section{Conflicts of Interest}

Authors declare no conflict of interest regarding the publication of the paper.

\section{References}

[1] Cramer, W., Guiot, J., Fader, M. Garrabou, J., Gattuso, J.P., Iglesias, A., Lange, M.A., Lionello, P., Llasat, M.C., Paz, S., Peñuelas, J., Snoussi, M., Toreti, A., Tsimplis, M.N. and Xoplaki, E. (2018) Climate Change and Interconnected Risks to Sustainable Development in the Mediterranean. Nature Climate Change, 8, 972-980. https://doi.org/10.1038/s41558-018-0299-2 
[2] Schiermeier, Q. (2014) Water Risk as World Warms. Nature, 505, 10-11. https://doi.org/10.1038/505010a

[3] Droogers, P., Immerzeel, W.W., and Lorite, I.J. (2010) Estimating Actual Irrigation Application by Remotely Sensed Evapotranspiration Observations. Agricultural Water Management, 97, 1351-1359. https://doi.org/10.1016/j.agwat.2010.03.017

[4] Schewe, J., Heinke, J., Gerten, D., Haddeland, I., Arnell, N.W., et al. (2014) Multimodel Assessment of Water Scarcity under Climate Change. Proceedings of the National Academy of Sciences of the United States of America, 111, 3245-3250. https://doi.org/10.1073/pnas.1222460110

[5] Banerjee, S., Chatterjee, S., Sarkar, S. and Jena, S. (2016) Projecting Future Crop Evapotranspiration and Irrigation Requirement of Potato in Lower Gangetic Plains of India Using the CROPWAT 8.0 Model. Potato Research, 59, 313-327. https://doi.org/10.1007/s11540-016-9327-7

[6] Cohen, S., Ianetz, A. and Stanhill, G. (2002) Evaporative Climate Changes At Bet Dagan, Israel, 1964-1998. Agricultural and Forest Meteorology, 111, 83-91. https://doi.org/10.1016/S0168-1923(02)00016-3

[7] Bates, B., Kundzewicz, Z.W., Wu, S. and Palutikof, J. (2008) Climate Change and Water. Technical Paper Vi, Intergovernmental Panel on Climate Change (IPCC), Geneva.

[8] Willmott, C.J., Rowe, C.M., and Mintz, Y. (2007) Climatology of the Terrestrial Seasonal Water Cycle. International Journal of Climatology, 5, 589-606. https://doi.org/10.1002/joc.3370050602

[9] Zhou, M.C., Ishidaira, H. and Takeuchi, K. (2008) Comparative Study of Potential Evapotranspiration and Interception Evaporation by Land Cover over Mekong Basin. Hydrological Process, 22, 1290-1309. https://doi.org/10.1002/hyp.6939

[10] Hargreaves, G.H. and Samani, Z.A. (1982) Estimating Potential Evapotranspiration. Journal of the Irrigation and Drainage Division, 108, 225-230.

[11] Pidwirny, M. (2006) Fundamentals of Physical Geography. 2nd Edition. Online E-Book. http://www.physicalgeography.net/fundamentals/8j.html

[12] Zhou, M.C., Ishidaira, H., Hapuarachchi, H.P., Magome, J., Kiem, A.S. and Takeuchi, K. (2006) Estimating Potential Evapotranspiration Using Shuttleworth-Wallace Model and NOAA-AVHRR NDVI Data to Feed a Distributed Hydrological Model over the Mekong River Basin. Journal of Hydrology, 327, 151-173. https://doi.org/10.1016/j.jhydrol.2005.11.013

[13] Kumar, M., Raghuwanshi, N.S., Singh, R., Wallender, W.W. and Pruitt, W.O. (2002) Estimating Evapotranspiration Using Artificial Neural Network. Journal of Irrigation and Drainage Engineering, 128, 224-233. https://doi.org/10.1061/(ASCE)0733-9437(2002)128:4(224)

[14] Jensen, M.E., Burman, R.D. and Allen, R.G. (1990) Evapotranspiration and Irrigation Water Requirements. ASCE Manuals and Reports on Engineering Practice No. 70. American Society of Civil Engineers, New York.

[15] Allen, R.G., Walter, I.A., Elliot, R.L., Howell, T.A., Itenfisu, D., Jensen, M.E. and Snyder, R. (2005) The ASCE Standardized Reference Evapotranspiration Equation. ASCE and American Society of Civil Engineers, Reston. https://doi.org/10.1061/9780784408056

[16] Banerjee, S., Mukherjee, A., Das, S. and Saikia, B. (2014) Adaptation Strategies to Combat Climate Change Effect on Rice and Mustard in Eastern India. Mitigation and Adaptation Strategies for Global Change, 21, 249-261. 
https://doi.org/10.1007/s11027-014-9595-y

[17] Boomiraj, K., Chakrabarti, B., Aggarwal, P.K., Choudhary, R. and Chander, S. (2010) Assessing the Vulnerability of Indian Mustard to Climate Change. Agriculture, Ecosystems \& Environment, 138, 265-273 https://doi.org/10.1016/j.agee.2010.05.010

[18] FAO (1992) CROPWAT: A Computer Program for Irrigation Planning and Management. Irrigation and Drainage Paper No. 46, FAO, Rome.

[19] Riahi, M., Jumaily, K. and Kamies, I. (2003) Measurements of Net Radiation and Its Components in Semi-Arid Climate of Baghdad. Energy Conversion and Management, 44, 509-525. https://doi.org/10.1016/S0196-8904(02)00075-4

[20] Verma, I.G., Jadhav, V.N. and Erande, R.S. (2008) Recent Variations and Trends in Potential Evapotranspiration (PET) over India. Mausam, 59, 119-128.

[21] Tao, X.E., Chen, H., Xu, C.Y., Hou, Y. and Jie, M.X. (2015) Analysis and Prediction of Reference Evapotranspiration with Climate Change in Xiangjiang River Basin, China. Water Science and Engineering, 8, 273-281.

https://doi.org/10.1016/j.wse.2015.11.002 